\title{
BRAF Gene Amplification
}

National Cancer Institute

\section{Source}

National Cancer Institute. BRAF Gene Amplification. NCI Thesaurus. Code C133674.

A molecular genetic abnormality indicating the presence of multiple copies of the BRAF gene. 